\title{
Hypnoteaching and Hypnolearning in Mathematics Education
}

\author{
Hamzah Upi ${ }^{1}, \mathrm{Ja}^{\prime}$ faruddin ${ }^{2}$ \\ \{hamzahupu@gmail.com ${ }^{1}$, jafaruddin@unm.ac.id $\left.{ }^{2}\right\}$ \\ Department of Mathematics, Universitas Negeri Makassar, Indonesia ${ }^{1}$, Department of Applied \\ Mathematics, Tunghai University, Taichung 40704, Taiwan ${ }^{2}$
}

\begin{abstract}
The aims of this study are to determine the differences in students' achievement and their motivation in comparations of two Hypnoteaching and hypnolearning models. The study was a quasi-experimental setting with two groups. The experimental one used the Ericson Model and the experimental two with the Elman Model. The sampling technique was purposive sampling. Data were gathered by achievement test and learning motivation questionnaire. The results show that; (1) mathematics learning achievement of students with the Ericson Model is in the high category. Meanwhile, Elman Model is in the medium category. Students' motivation to learn mathematics in both classes are presented in the high category. The results also show that although there were no significant differences in students' motivation to learn mathematics, student achievement for the Ericson Model is better than the classes using the Elman Model.
\end{abstract}

Keywords: Hypnoteaching, Ericson, Elman, and Model

\section{Introduction}

The self-concept and student's perceptions of teachers or mathematics lie in the subconscious mind. Erickson and Elman's models are models that can be done to change students' self-concepts and perceptions. In addition, hypnoteaching can be done by programming student's subconscious, so that the self-concept of mathematics becomes better, changing perceptions and making students always excited during learning, which in turn to make students competent unconsciously [1].

Badura asserted that observational learning, commonly called modeling or imitation that done by someone by observing, imitating or taking lessons from others [2]. Abraham H. Maslow with his hierarchy of needs, consisting of physiology encouraging biological gratification, such as hunger, thirst, sexual drive or rest, security with a sense, free from fear, love and a sense encouraging social contact, self-esteem self-respect and self-actualization, for which that drives self-realization [2].

Humanistic theory becomes the basis for Hypnoteaching in which always introduces to the "the good" side of humans, in this case to students by developing unconditional positive regard and empathy. Teachers are expected to always give "a positive energy" to students, with the hope, that students always motivated them every single day, especially in learning.

Nurindah said that the subconscious mind can be programmed. Such programs of computers', in which the program can be reinstalled, modified or changed with new programs. One way to access students' subconscious minds is by using Hypnosis [3,4]. Hypnosis can 
change and grow many things in a person's life, including improving the ability to solve problems and improve achievement as a purpose [1]. This is reinforced by Macgregor that Hypnosis can improve learning achievement and motivation. Thus, by doing hypnoteaching and hypnolearning, students can be motivated and their learning achievement increases. Physically, hypnosis programming utilizes brain waves [4], namely Alpha and Theta waves. The formation of anchors is also very important in programming the student's subconscious mind. The anchor is a stimulus that if it occurs will trigger a certain feeling or emotion [5]. Ancor formation is strongly influenced by the levels of awareness (trans) of a person at the time the unconscious program takes place. The appropriate level of awareness (trans) will make the formation of Ancor better and more effective.

The steps in Hypnoteaching are, (1) pacing and leading, (2) "Genius" anchor (3) Environmental learning (4) "energizer" anchor (5) Unconscious writing through mind mapping (6) reflection through relaxation [6]. In accordance with, some important steps of hypnoteaching are;

Firstly, it is to equalize the frequency between students and teachers by means of physiological equalization, which is then carried out by the teacher for the next step by triggering their anchors to stimulate positive emotion. Secondly, distinguishes between motivation conditions in learning with other teaching and learning approach. Thirdly, teachers facilitate students to internalizing the material. When the students' condition starts to look less enthusiastic, it is necessary to trigger an emotional energizer anchor that makes them fresh and enthusiastic again. The thing that needs to be practiced is that the emotional anchor of the energizer can be formed at the beginning of the teaching and learning process. The last step is to reflex the subject matter which is done in a relaxed manner. Students are guided to enter the relaxed conditions and reflect on the material that they have been studied in the classroom.

Ericson's Hypnoteaching Model uses metaphorical techniques through analogies and stories that seem unrelated to student problems. The thing to note from Erickson's technique is the importance of paying attention to the language patterns used in giving suggestions. On the other hand, Elman Hypnoteaching Model is based on progressive relaxation induction [6,7]. This technique has been modified several times from the original, but still consists of three components, namely, body relaxation, relaxation of the mind and deepening relaxation [8].

\section{Method}

This study is quantitative research with Quasi Experiment. The study was conducted by manipulating variables by giving treatment to two groups in class XII IPS in SMA YPS Soroako ( YPS Soroako Senior High Scholl). The treatment for a group I was learning mathematics through Ericson's Hypnoteaching Model and group II was learning mathematics through Elman's Model. The variables observed in this study were students' mathematics learning achievement and motivation.

The population of this study was all students of Class XII of SMA YPS Soroako in East Luwu consisting of 2 classes. The sampling technique used was the saturating Sampling technique.

The data were collected on mathematics achievement tests and student motivation questionnaire. Data were analyzed with one-way manova. Before the data analysis was performed, the Normality, Homogeneity and Equivalence of the Matrix of Covariance. 


\section{Results and Discussion}

\section{Results of Descriptive Statistics Analysis}

The characteristics of respondents both mathematics learning achievement data and mathematics learning motivation are described in Descriptive Statistics. Table 1 is summary of descriptive analysis of motivation in mathematics.

Table 1. Summary of Descriptive Analysis of Math learning achievement.

\begin{tabular}{ccc}
\hline \multirow{2}{*}{ Statistics } & \multicolumn{2}{c}{ Models } \\
& Ericson Hypnoteaching Model & Elman Hypnoteaching Model \\
\hline Subject & 15 & 13 \\
Ideal Score & 80 & 80 \\
Highest score & 79 & 80 \\
Lowest score & 44 & 21 \\
Score Range & 35 & 59 \\
Average score & 62,4 & 50,23 \\
Variance & 105,829 & 268,026 \\
Standard & 10,287 & 16,371 \\
deviation & & \\
\hline
\end{tabular}

Next, a summary of Descriptive Analysis of Motivation to learn mathematics in Table 2.

Table 2. Summary of Descriptive Analysis of motivation in mathematics.

\begin{tabular}{llc}
\hline \multicolumn{1}{c}{ Category } & \multicolumn{2}{c}{ Percentage } \\
& Ericson Hypnoteaching Model & Elman Hypnoteaching Model \\
\hline very low & $0,00 \%$ & $0,00 \%$ \\
low & $13,33 \%$ & $15,38 \%$ \\
high & $46,67 \%$ & $38,46 \%$ \\
very high & $40,00 \%$ & $46,15 \%$ \\
& & \\
\hline
\end{tabular}

Hypothesis testing about the mean cell parameter vectors used by the F-Test Statistics and to test the Hypothesis based on the Linear Multivariate Model namely Statistics Wilks' Lamda $(\wedge)$.

Summary of Hypothesis Testing in the following Table 3:

Table 3. One Path Analysis of Multivariate Variance (Manova).

\begin{tabular}{lccccc}
\hline $\begin{array}{l}\text { Source of } \\
\text { Variance }\end{array}$ & $\begin{array}{c}\text { Matriks SS and cross } \\
\text { products }\end{array}$ & & & & \\
& & & & & \\
& & & & & \\
\hline Treatment & $\left(\begin{array}{cc}3994.2 & 582,676 \\
582,676 & 169,54\end{array}\right)$ & 2 & & & \\
Error (E) & $\left(\begin{array}{rr}5881,24 & -1450,9 \\
-1450,9 & 3964,5\end{array}\right)$ & 40 & 7,3 & 0,00 & $2,48 *$ \\
Total & $\left(\begin{array}{rr}9875,44 & -868,21 \\
-868,21 & 4134,05\end{array}\right)$ & 42 & & & \\
\hline
\end{tabular}


Description: * Significant to $\propto=0,05$

Based on the results of data analysis using one-way MANOVA as noted in Table 3 shows that the value of Wilks' Lamda $(\Lambda) \mathrm{F}_{\text {statistic }}=7.3$ is much greater than the value of $\mathrm{F}$ table $=(2.48)$ or the value of $\mathrm{p}=0.00<\propto=0.05$ or this means that $\mathrm{H}_{0}$ is rejected or accepts $\mathrm{H}_{1}$. Thus, there are differences in students' achievement and motivation in learning mathematics between the Ericson Hypnoteaching Model approach and Elman's Hypnoteaching Model.

Further tests were conducted to determine the differences between the two groups, the Ericson Hypnoteaching Model and the Elman Hypnoteaching Model, then proceed to the Univariate Variant analysis model.

Univariate variant analysis

The following table summarizes the results of testing the hypotheses presented in Table 4 .

Table 4. Analysis of the Hypothesis testing of the univariate parameters.

\begin{tabular}{lccccc}
\hline $\begin{array}{l}\text { Dependent } \\
\text { Variable }\end{array}$ & $\begin{array}{c}\text { Type III Sum of } \\
\text { Squares }\end{array}$ & Df & Mean Square & F & Sig. \\
\hline $\begin{array}{l}\text { Mathematics } \\
\text { Learning }\end{array}$ & $3994.201(\mathrm{a})$ & 2 & 1997.100 & 13.583 & .000 \\
$\begin{array}{l}\text { Achievement } \\
\text { Learning }\end{array}$ & & & & & .855 \\
$\begin{array}{l}\text { Motivation in } \\
\text { Mathematics }\end{array}$ & $169.544(\mathrm{~b})$ & 2 & 84.772 & .433 \\
\hline
\end{tabular}

Based on the results of data analysis and testing of hypotheses in Table 4, shows that $\mathrm{p}$ value greater than $\propto=0.05$, this means, receiving $\mathrm{H}_{0}$. There are differences in the level of student mathematics learning achievement between the Ericson and the Elman Models. However, there was no significant difference in students' motivation to learn mathematics between the Ericson Hypnoteaching Model and the Elman Model.

Data analysis shows that the significant value is 0.012 if it is compared with the significance level $\propto=0.05$, then a significant correlation $\mathrm{p}<\propto$ is obtained, which means rejecting $\mathrm{H}_{0}$ or accepting $\mathrm{H}_{1}$. There are significant differences between the mathematics learning experimental classes through the Ericson Model Elman Model. Mathematics learning through the Ericson Model is better than Elman Model in terms of improving mathematics learning achievement. This can be seen in the average score of mathematics learning through the Elman approach that is 62.4 with a Standard Deviation of 10.287 which is greater than the average score of the mathematics learning experimental class through the Elman Model of 50.23 with a Standard Deviation of 16.371 .

Table 7 is summarizes the results of Post Hoc-LSD data analysis

Table 7. Significance Value (p) of the Post Hoc Test-LSD results.

\begin{tabular}{llcccc}
\hline Variable & & Class & Mean Difference & Std. Error & Sig. \\
\hline $\begin{array}{l}\text { Mathematics } \\
\text { Learning }\end{array}$ & Eks1 & Eks2 & $12.1692(*)$ & 4.59480 & .012 \\
Achievement & Eks2 & Eks1 & $-12.1692(*)$ & 4.59480 & .012 \\
\hline
\end{tabular}

Notes :

Eks1 = Data Mathematics Achievement Learning HYPNOTEACHING Ericson Model Eks2 = Data Elman HYPNOTEACHING Mathematics Learning Achievement Data 


\section{Discussion}

The results of the multivariate analysis of variance show that there are significant differences in the level of achievement and motivation of students' mathematics learning between the Ericson and the Elman Models. The difference is caused that the suggestion in Ericson's technique was indirect suggestions through metaphors or stories and anchoring that directly affect the students' subconscious minds. Elman's technique on the other side, suggestions are given after students are in a level trance so that, suggestions are accepted or rejected by the subconscious mind. Apart from the different results, This is in line with the theory that puts forward by Ericson and Elman that to affect the subconscious mind can be done using Hypnoteaching both the Ericson Model and the Elman Model.

Based on the results of multivariate variance analysis, there are significant differences between students, through the Ericson and Elman Models. In general, Ericson's and Elman's Models are better in terms of improving students' mathematics learning achievement. This is in line with Ericson and Elman that to touch the subconscious mind can be done using Hypnoteaching $[3,4]$. Thus, if a student, who is touched by their subconscious mind will reach unconscious competence. This is consistent with the theory by Bavister that the Unconscious Mind Program will make an Unconscious Competence, in other words, someone will be competent unconsciously in this case to achieve mathematics learning achievement. This is also in line with the case study of Gunawan, who found there was a significant increase in learning achievement after the hypnosis process.

The results of the multivariate variant analysis also show that Ericson Model was better than Elman Model in terms of improving student learning outcomes. This supports the theory put forward by O.Brien, who revealed that Ericson's technique is better than Elman's techniques. The researchers' observations revealed that there were students, who were rather difficult to induce. This reinforces the suspicion from researchers that these students may be resistant to suggestions or have problems with sleep. In relation to the ways of solving problems, Upu Hamzah, Djadir \& Asyari, Syahrullah reported that mathematics ability and students' mathematics experiences are three indivisible aspects when solving mathematics problems [9]. In the Ericson Model class, the suggestions given were not able to be rejected by the students' conscious mind because the suggestions were disguised in stories and metaphors.

Based on the results of multivariate variance analysis, there is no significant difference between students who are taught mathematics through the approach of Ericson's and Elman's Models in terms of learning motivation in mathematics. It should be noted that in general, the learning motivation of these two classes is in the high category. This is consistent with the theory by Experts (Gagne and Berliner, Uno, Sudirman, Ericson, and Elman), which states that the two approaches made will increase motivation to learn in terms of this motivation to learn mathematics.

The results show there were no significant differences in the level of motivation to learn mathematics with the approach of Ericson's and Elman's Models. This shows consciously (students' conscious competence), that they are motivated. Students who are given hypnoteaching treatment, their motivation can be stimulated unconsciously, so that students are always excited and always focused on learning. Hypnoteaching students Class are more excited than not being given Hypnoteaching. Mathematics learning through Hypnoteaching, both Ericson's and Elman's Models, proved to be better in terms of improving mathematics learning achievement. 


\section{Conclusions and Suggestions}

\section{Conclusion}

Based on the results of research and discussion that has been stated in the previous chapter, the following conclusions can be drawn:

1) The level of students' mathematics learning achievement in the learning process through the Ericson Model is in a high category, mathematics learning through the Elman Model is in the medium category.

2) The level of motivation to learn mathematics through Ericson Model and Elman Model is very high.

3) Mathematics learning through the Ericson Model and Elman Model differ significantly in terms of the level of achievement and motivation of students in learning mathematics.

4) The level of student mathematics learning achievement in learning mathematics through the Ericson Model approach is better than Elman's Model.

5) In terms of students' mathematics learning motivation, it is no significant difference of Learning mathematics through the approach of the Ericson Model and Elman Model.

\section{Suggestions}

This study shows the need for a further elaboration of hypnoteaching research in mathematics education. Such as how to mixing two models and apply them to another level of education and reduce some obstacles in this approach. Furthermore, for the wider application will impact the teachers' needs to be trained in this approach

\section{References}

[1] Goldberg, B.: Self Hypnosis . Yogyakarta: B-First (2006)

[2] Santrock., John, W.: Psikologi Pendidikan. Jakarta: Kencana (2007)

[3] La Kahija, Y.F.: Hipnoterapi. Jakarta: Gramedia Pustaka Utama (2007)

[4] Gunawan, A.W.: Hypnotherapy The Art of Subconscious Restructuring. Jakarta: Gramedia Pustaka Utama (2007)

[5] Bavister, S., Amanda V.: NLP for Personal Success. Yogyakarta: Pustaka Baca (2004)

[6] Ja'faruddin.: Hypnoteaching as A Teaching Model, Proceeding , International Confrence on Mathematics, Science, Technology, Education and Their Application; ISBN:979-604-151-0 , State University of Makassar Indonesia. pp. 20-21 (2014)

[7] Ja'faruddin.: Unconscious Mind Program dalam Pembelajaran Matematika. Tesis tidak diterbitkan. Makassar: UNM Makassar (2010)

[8] Elman, D.: Hypnotherapy. Glendale, CA: Westwood Publishing CO (1977)

[9] Upu, H. Djadir, \& Asyari, S.: The fifth grader's mathematisation process in solving contextual problems. World Transaction on Engineering and Technology Education, Vol. 15. No. 2. pp. 195-199 (2017) 